\title{
ANALISIS VALIDITAS PREDIKSIBILITAS UJIAN MASUK TERHADAP HASIL BELAJAR SATU TAHUN KEDEPAN DI MTS ALI MAKSUM
}

\author{
Laelatul Badriah \\ (Dosen PGMI Sekolah Tinggi Ilmu Agama Alma Ata Yogyakarta)
}

\begin{abstract}
ABSTRAK
Improving student learning outcomes can be known through examination or evaluation of student learning outcomes, as well as to improve the quality of education at a particular Islamic Junior Secondary School (MTs) Ali Maksum that can be seen through the entrance test the institution itself. Entrance test could be determine the quality of student learning outcomes, therefore it is very important be re-examined or entrance test kits that is used to determine the graduation of new students. Entrance tests can also determine the outcome of the first year students in the first and second semester. In this case retesting can be done by looking at the results of the entrance test, the results of the 1 st semester final exam, and the results of the final exams 2 that is analyzed using multiple regression. This analysis is used to predict the results of the entrance test and see how much influence the results of the 1 st semester final exams and final exams 2. From the discussion, it is a result of its high predictive significance between entrance exams, final exams 1, 2 and semester exams in the first year in MTs Ali Maksum.
\end{abstract}

Keywords : Entrance test, predictabilities, validity

\section{A. PENDAHULUAN}

Salah satu permasalahan pendidikan yang dihadapi oleh bangsa Indonesia adalah rendanya mutu pendidikan pada setiap jenjang pendidikan dan satuan pendidikan. Kualitas pendidikan dilihat dari asfek efisiensi dan prestasi belajar.

Saat ini pemerintah sedang giat melakukan otonomi daerah, maka tidak ketinggalan pemerintah kabupaten bantul lewat dianas pendidikan 
dan kebudayaan juga berkepentingan untuk menyelenggarakan otonomi dalam bidang pendidikan. Untuk itu pemerintah kabupaten bantul menyusun suatu rencana strategis dalam dunia pendidikan, yang dapat menjamin terlaksananya pendidikan yang dapat meningkatkan kualitas sumber daya manusia serta pemerataan kesempatan warga untuk mendapatkan pendidikan yang seluas-luasnya dan bermutu.

Mulai tahun pelajaran 2002/2003 program penerimaan siswa sekolah menengah pertama (SMP) menggunakan system seleksi, dengan tes sesuai dengan surat keputusan menteri pendidikan nasional nomor: $51 / \mathrm{U} / 2002$, dengan pertimbangan bahawa (1) penerimaan siswa baru dengan cara yang lebih baik dapat meningkatkan mutu pendidikan dan mencapai sumber daya manusia yang berkualitas sesuai dengan kompetensi yang ditetapkan secara nasional (2) dalam rangka pemberdayaan sekolah dengan prinsip manajemen berbasis seolah, perlu lebih banyak memberikan kewenangan pada sekolah dalam penyelengaraan penerimaan siswa baru.

Menurut Nana Sudjana penilaian selektif atau ujian masuk adalah penilaian yang bertujuan untuk keperluan seleksi1, misalnya ujian saringan masuk lembaga pendidikan tertentu. Maka seleksi dapat dipahami sebagai suatu kegiatan untuk memilih pendaftaran pada suatu program yang telah direncanakan untuk mendapatkan peserta yang terbaik, dengan mempergunakan prangkat tes seleksi yang baik dan sesuai dengan ketentuan. Dengan mengetahui criteria siswa yang diterima, maka sekolah dapat memprediksi keberhasilan siswa yang diterima, maka sekolah dapat mempredksi akibat kesalahan pengukuran.

Tes seleksi masuk sangat menentukan nasib pesrta tes yaitu diterima atau tidaknya disuatu sekolah. Sehubungan dengan hal itu, maka instrument seleksi yang berupa soal-soal seleksi harus berkualitas, harus dapat memiliki daya prediksi, sehingga dapat memprediksikan kemampuan dan keberhasilan siswa dimasa yang akan datang. Kualiatas tes ini berkatan dengan kemampuan apakah tes tersebut dapat mengestimasi seluruh potensi yang dimiliki siswa, sehingga dapat memilih peserta yang berkualitas. Dengan dipilihnya siswa yang berkualitas diharapkan dapat dicapai kualitas pendidikan yang baik, karena kualitas siswa adalah unsure utama yang menentukan keberhasilan siswa dalm belajar.

${ }^{1}$ Nana Sudjana, Penilaian Hasil Proses Belajar Mengajar, (Bandung: Remaja Rosdakarya, Bandung, 2002), hlm. 5 
Pada program penerimaan siswa baru tingkat SMP/ MTS, ada ketentuan yang harus dipatuhi oleh semua sekolah, bahwa sekolah dapat mengadakan seleksi calaon siswa baru, jika penfaftar melebih daya tampung sekolah yang bersangkutan, sehingga apabila suatu sekolah jumlah pendaftara yang kurang dari daya tampug tidak diperkenankan mengadakan tes seleksi. Mata pelajaran yang di ujikan adalah matematika, IPA, IPS, dan Bahasa. Namun di Madrasah Tsanawiyah Ali Maksum yang diujikan dalam tes masuk adalah tes logika. Sedangkan penetapan penerimaan siswa baru kelas VII MTs dengan mendasarkan pada jumlah nilai komulatif hasil tes dan nilai prestasi akademik.

Berkaitan dengan hal tersebut di atas, selanjutnya perlu diteliti seberapa besar daya prediksi perangkat tes yang digunakan dalam program tes seleksi masuk MTS Ali Maksum terhadap hasil belajar satu tahun pertama?

\section{B. LANDASAN TEORI}

Menurut Allen dan Yen (1979: 101) dikutip Kabul Mulyana bahwa pengambilan keputusan dianggap tepat jika pada seleksi pendaftar yang diterima akan berhasil dalam mengikuti kegiata pembelajaran dan calon siswa yang diterima akan gagal dalam mengikuti kegiatan pembelajaran.2 Artinya pada tes seleksi masuk sekolah siswa yang diterima akan berhasil dalam mengikuti kegiatan pembelajaran dan siswa yang ditolak akan gagal dalam mengikuti kegiatan pembelajaran. Dengna demikian tes selksi ini juga bertujuan untuk penempatan kelas bagi pendaftar yang diterima, maka penilaian selektif berkaiatan dengan penempatan.

Menurut Allen dan Yen (1979: 101) yang dikutip Kabul Mulyana3 dan Sumardi Suryabrata (2005:28) menggambarkan putusan seleksi sebagai berikut:

${ }^{2}$ Kabul Mulyana, Jurnal Penelitian dan Evaluasi Pendidikan Karakteristik. Soal Tes Ujian Masuk SMP Negeri Kabupaten Bantu. (Yogyakarta: Universitas Yogyakarta, 2006), hlm. 28

${ }^{3}$ Kabul Mulyana, Jurnal Penelitian dan Evaluasi Pendidikan ......, hlm. 29 
Tabel 1

Keputusan Seleaksi

\begin{tabular}{|c|c|c|}
\hline Hasil & Berhasil & Gagal \\
\hline Berhasil & Benar & Salah \\
\hline Gagal & Salah & Benar \\
\hline
\end{tabular}

Penilaian diartikan sebagai menentukan nilai suatu objek. Untuk menentukan nilai atau harga diperlukan adanya ukuran atau kriteria. Dengan demikian inti penilaian adalah proses memberikan atau menentukan nilai kepada objek tertentu berdasarkan suatu kriteria tertentu.4 Penilaian hasil belajar adalah proses pemberian nilai-nilai terhadap hasil belajar yang dicapai oleh siswa dengan kriteria tertentu. Hasil belajar siswa hakikatnya adalah perubahan tingkah laku siswa.

Menurut Howard Kingsley yang dikutip oleh Nana Sudjana (1987) membagi tiga macam hasil belajar, yakni keterampilan dan kebiasaan, pengetahuan dan pengertian, dan sikap dan cita-cita.5 Hasil belajar erat kaiatannya dengan prestasi belajar, untuk mengetahui hasil belajar maka perlu adanya evaluasi dan penilain terhadap hasil belajar siswa. Penilaian hasil belajar adalah proses pemberian nilai-nilai terhadap hasil belajar yang dicapai oleh siswa dengan kriteria tertentu. Hasil belajar siswa hakikatnya adalah perubahan tingkah laku siswa. Adapun fungsi penilaian adalah sebagai selektif, diagnositik, penempatan, dan pengukuran keberhasilan.6

Pada penelitian ini teori hasil belajar yang digunakan adalah teorinya Bloom yang terdiri dari tiga ranah yakni ranah kognitif, ranah afektif, dan ranah psikomotor. Dalam hubungan dengan satuan pengajaran, ranah kognitif memegang peran penting. Yang menjadi tujuan pengajaran di sekolah pada umumnya adalah peningkatan siswa dalam asfek kognitif. Dalam hal ini Taksonomi Bloom (1956) membedakan enam jenjang yang diurutkan secara hierarki pyramidal.7 Pengukuran hasil belajar berupa prestasi belajar cenderung pada aspek atau ranah kognitif dari seorang

${ }^{4}$ Nana Sudjana, Penilaian Hasil Proses Belajar Mengajar, (Bandung: Remaja Rosdakarya, Bandung, 2002), hlm.3

${ }^{5}$ Nana Sudjana, Dasar-dasar proses belajar mengajar. (Bandung: Sinar baru Algasindo, 1986). hlm. 45

${ }^{6}$ Suharsimi Arikunto, Dasar-dasar evaluasi pendidikan (edisi revisi), Jakarta: Bumi Aksara, 2006). hlm. 10

${ }^{7}$ Daryanto, Evaluasi pendidikan, (Jakarta: Rineka Cipta, 2005). hlm. 101 
siswa. Dalam hal ini, alat yang digunakan adalah tes. Tes merupakan sejumlah pertanyaan yang memiliki jawaban yang benar atau salah. Hasil tes merupakan informasi tentang karakteristik seseorang atau sekelompok orang. Karakteristik ini bisa kemampuan atau keterampilan seseorang. Tes merupakan salah satu cara untuk menaksir besarnya tingkat kemampuan manusia secara tidak langsung, yaitu melalui respon seseorang terhadap sejumlah stimulus atau pertanyaan. Oleh karena itu agar diperoleh informasi yang akurat dibutuhkan tes yang handal. 8

Prestasi menurut bahasa adalah hasil yang telah dicapai (dari yang telah dikerjakan atau dilakakukan).9 Berdasarkan definisi tersebut, prestasi dapat diartikan sebagai hasil yang diperoleh seseorang dari pengalamannya, baik itu pengalaman kerja ataupun pengalaman belajar, yang semuanya itu diperoleh dari kerajinan atau keuletan seseorang baik dalam bekerja maupun dalam belajar. Adapun yang dimaksud prestasi dalam konteks tulisan ini adalah prestasi yang dicapai oleh siswa dalam proses belajar mengajar.

Syaiful Djamarah berpendapat bahwa "prestasi adalah hasil yang telah dikerjakan, diciptakan (baik secara individu ataupun kelompok). Jadi prestasi ini ialah hasil dari sesuatu yang diperoleh kalau seseorang tersebut telah melakukan suatu kegiatan. Sementara Harun Harahap dkk, memberikan batasan bahwa prestasi adalah penilaian pendidikan tentang perkembangan dan kemajuan murid, yang berkenaan dengan penguasaan bahan pelajaran serta nilai-nilai yang terdapat dalam kurikulum. Sedangkan Mas'ud Hasan Abdul Kohar, prestasi itu adalah apa yang telah didapat atau diciptakan, hasil yang menyenangkan hati yang diperoleh dari suatu kegiatan yang telah diperoleh dengan jalan keuletan kerja.

Prestasi adalah suatu hasil yang dicapai oleh siswa setelah melakukan suatu kegiatan dalam hal ini adalah proses belajar. Belajar merupakan suatu proses perubahan, yaitu perubahan dalam perilaku sebagai hasil dari interaksi dengan lingkungannya dalam memenuhi kebutuhan hidupnya. 10

Jadi prestasi belajar adalah hasil yang telah dicapai secara maksimum oleh seseorang yang telah melakukan kegiatan belajar. Jadi prestasi belajar

${ }^{8}$ Djemari Mardapi, Teknik pemyusunan instrumen tes dan non tes. (Yogyakarta: Mitra Cendikia Perss, 2007). hlm. 67

${ }^{9}$ W.J.S. Poerwadarminta, Kamus Umum Bahasa Indonesia, cet. Ke-8 ( Jakarta: Balai Pustaka, 1985), hlm. 768

${ }^{10}$ Nurjan, Syarifan, dan kawan-kawan. Psikologi Belajar. (Surabaya: LAPISPGMI, 2009), hlm.2-15 
pada penelitian ini adalah prestasi belajar matematika yaitu hasil yang telah dicapai oleh siswa pada mata pelajaran matematika setelah mengalami proses belajar. Secara umum ada dua macam fungsi yang dimiliki oleh tes yaitu $^{11}$ :

1. Sebagai alat pengukur terhadap siswa. Dalam hal ini mengukur tingkat perkembangan atau kemajuan yang telah dicapai oleh siswa setelah menempuh proses pembelajaran.

2. Sebagai alat pengukuran keberhasilan program pengajaran, sebab melalui tes tersebut dapat diketahui sudah seberapa jauh program pengajaran yang telah ditentukan telah tercapai.

Faktor yang mempengaruhi hasil belajar siswa, hasil belajar siswa dipengaruhi oleh dua faktor yaitu faktor dalam dan faktor luar dari diri siswa secara langsung. Secara garis besar faktor-faktor yang mempengaruhi hasil belajar siswa adalah:

1. Faktor dalam yang meliputi $:^{12}$

a. Kondisi fisiologi

Kondisi fisiologi pada umumnya berpengaruh terhadap belajar seseorang, jika seseorang belajar dalam keadaan jasmani yang segar akan berbeda dengan seseorang yang belajar dalam keadaan sakit.

b. Kondisi psikologis

Beberapa faktor psikologis antara lain :

(1) Kecerdasan

Kecerdasan seseorang besar pengaruhnya dalam keberhasilan siswa dalam mempelajari sesuatu.

(2) Bakat

Selain kecerdasan, bakat juga besar pengaruhnya terhadap proses dan hasil belajar siswa.

(3) Minat

Jika seseorang mempelajari sesuatu dengan minat yang besar, maka dapat diharapkan hasilnya akan lebih baik. Tetapi jika seseorang belajar dengan tidak berminat maka hasil yang diperoleh kurang baik.

${ }^{11}$ Anas Sudjiono, Pengantar evaluasi pendidikan, Jakarta: PT. Raja Gravindo Persada, 1998), blm. 167 2007), hlm.74.

${ }^{12}$ Sugihartono,dkk, Psikologi Pendidikan Cet. A, (Yogyakarta: UNY Press, 
(4) Motivasi

Motiasi adalah dorongan anak atau seseorang untuk melakukan sesuatu, jadi motivasi adalah kondisi psikologi yang mendorong seseorang untuk belajar. Pada dasarnya hubungan motivasi dengan belajar adalah bagaimana cara mengatur motivasi yang dapat ditingkatkan supaya hasil belajar dapat optimal sesuai dengan kemampuan individu

(5) Kemampuan Kognitif

Kemampuan kognitif atau kemampuan penalaran yang tinggi akan membantu siswa dapat belajar lebih baik dari

2. Faktor Luar pada siswa yang memiliki kemampuan kognitif sedang.

Yaitu faktor yang berasal dariluar diri siswa yang dapat mempengaruhi hasil belajar siswa. Beberapa faktor luar antara lain:

a. Faktor Lingkungan, antaralain:

(1) Lingkungan alam

(2) Lingkungan sosial, baik yang berwujud manusia atau yang lain yang langusng dapat mempengaruhi proses dan hasil belajar.

b. Faktor Instrumen

Adalah faktor-faktor yang ada dan penggunaannya dirancang sesuai dengan hasil belajar yang diharapkan. Faktor-faktor ini meliputi:

(1) Kurikulum

Kurikulum yang belum mantap dan sering adanya perubahan dapat mengganggu proses belajar

(2) Program

Program yang jelas tujuannya, sasarannya, waktunya mudah dilaksanakan, akan dapat membantuproses belajar

(3) Fasilitas

Keadaan gedung dan tempat belajar, penerangan, ventilasi, tempat duduk dapat mempengaruhi keberhasilan belajar. Sarana yang memadai akan membuat iklim yang kondusif untuk belajar

(4) Guru dan Tenaga Pengajar.

Kelengkapan jumlah guru, cara mengajar, kemampuan, kedisiplinan yang dimiliki oleh setiap guru dapat mempengaruhi proses dan hasil belajar siswa. Guru yang professional akan mengembangkan kemampuannya 
melalui pendekatan. Pendekatan akan mampu menciptakan suasana aktif sehingga tujuan yang direncanakan dapat tercapai. ${ }^{13}$

Adapun fungsi penilaian adalah sebagai selektif, diagnositik, penempatan, dan pengukuran keberhasilan.14 Menurut Nana Sudjana penilaian penempatan adalah penilaian yang bertujuan untuk mengetahui keterampilan prasyarat yang diperlukan untuk bagi suatu program belajar dan penguasaan belajar seperti yang diprogramkan sebelum masuk pada kegiatan tersebut. Dengan kata lain, penilaian ini berorientasi paa kesiapan siswa untuk menghadapi program baru dan kecocokan program belajar dengan kemampuan siswa.

Sehubungan dengan hal itu, agar dapat memilih pendaftar yang baik, yaitu pendaftar yaag diprediksikan berhasil dan ternyata memang berhasil dalam memgikuti kegiatan, maka diperlukan suatu perangkat tes seleksi yang baik. Menurut Djemari Mardapi, tes merupakan alat yang digunakan unuk pengukuran, yaitu mengumpulkan informasi karakteristik suatu objek.15 Respon siswa Terhadap pertanyaan menggambarkan kemampuan dalam bidang tertentu.

Realibilitas menurut Wiersma yang dikutip Kabul Mulyana adalah konsistensi suatu instrument pengukuran terhadapa apapun yang diukur atau dinilai, besarnya nilai koefisien reliabilitas mengambil angka dari 0 sampai 1,00.16 Realibilitas dapat juga dikatakan sebagai subjek derajat keajegan (conssitecy) diatara dua buah hasil pengukuran pada objek yang sama.

Pada waktu pengambilan keputusan dalam seleksi, ada beberapa syarat yang harus dipenuhi, menurut Sumardi Suryabrata (2005:26) syarat itu antara lain kecermatan prediksi, efisiensi ekonomi, dampak poditif terhadap proses brelajar mengajar dan keadilan. Selama ini keadilan yang diterapkan adalah memberikan kesempatan yang sama untuk mendaftar,

\footnotetext{
${ }^{13}$ Ibid.. .hlm.76.

${ }^{14}$ Suharsimi Arikunto, Dasar-dasar Evaluasi Pendidikan (Edisi Revisi), (Jakarta: Bumi Aksara, 2006), hlm. 10

${ }^{15}$ Djemari Mardapi, Teknik Penyusunan Instrumen Tes dan Non Tes, (Yogyakarta: Mitra Cendikia, 2008), hlm. 3

${ }^{16}$ Kabul Mulyana, Jurnal Penelitian dan Evaluasi Pendidikan ......, hlm. 30 
sehingga peluang untuk diterima ditentukan oleh sistem seleksi dan alat seleksi yang digunakan. ${ }^{17}$

Analisis kualitas suatu tes dapat dilihat atau diukur untuk mendapatkan hasil yang baik, salah satu alat tang diguankan adalah validitas. Vaditas merupakan untuk melihat kebenaran atau kesahihan suatu soal dan membandingkan skor yang dihasilkan peserta didik. Validitas mempunyai tiga karakteristik yaitu: Pertama, validitas sebenarnya menunjuk kepada hasil dari penggunaan instrument tersebut bukan pada instrument. Kedua, validitas menunjukkan suatu derajat atau tingkatan, validitasnya tinggi, sedang atau rendah, bukan valid dan tidak valid, dan Ketiga, validitas instrument juga memiliki spsifikasi tidak berlaku umum.

Selain tiga karakter validitas di atas, ada dua hal yang penting yaitu; pertama, menunjukan suatu erajat, ada yang sempurna, ada yang sedang, dan ada pula yang rendah. Kedua, validitas selalu dihubungkan dengan suatu putusan atau tujuan yang spesifik. 18 Selain itu Gronlund mengemukakan ada tiga faktor yang mempengauhi validitas yaitu faktor instrument evaluasi, faktor administrasi evaluasi dan penskoran, dan faktor jawaban dari peserta didik.19

Validitas instrument akan dapat diukur dengan memperhatikan beberapa faktor yang akan mempengaruhi hasil validitas dari suatu tes itu sendiri. Validitas ujian masuk ini diharapkan dapat memberikan nilai yang baik bagi peserta didik yang pada saat menempu studinya di tingkat pendidikan berikutnya atau ke jenjang yang lebih tinggi.

hlm. 3

${ }^{17}$ Saefudin Azwar, Reabilitas dan Validitas, (Yogyakarta: Pustaka Pelajar, 1997),

18Zaenal Arifin, Evaluasi Pembelajaran Prinsip Teknik Prosedur, (Bandung: PT. Remaja Rosda Karya, 2012), hlm. 274

${ }^{19} \mathrm{Ibid}, \mathrm{hlm} .278$ 


\section{METODE PENELITIAN}

Penelitian ini dirancang sebagai penelitian yang deskriptif kuantitatif dengan data berupa perangkat soal, hasil tes masuk dan nilai dua semester tahun pertama. Data yang ada di analisis dengan teori klasik dan teori respons butir, kemudian mendeskripsikan variabel yang akan diteliti dan menganalisis secara kuantitatif hubungan sebab akibat antar variabel. Yang dimaksudkan adalah pengaruh prediktor terhadap hasil belajar satu tahun pertama siswa MTs Ali Maksum tahun 2008/2009.

Subjek penelitian adalah butir soal tes masuk MTs Ali maksum dan nilai hasil belajar satu tahun pertama tahun ajaran 2008/2009 kelas VII yang diambil secara populasi. Yang berjumlah 85 siswa.

Tabel 2

Jumlah Peserta Tes yang Diterima di MTs Ali Maksum

\begin{tabular}{|c|c|c|c|}
\hline No. & Gelombang Tes & $\begin{array}{c}\text { Jumlah peserta } \\
\text { tes }\end{array}$ & $\begin{array}{c}\text { Jumlah yang } \\
\text { diterima }\end{array}$ \\
\hline 1 & I & 24 & 20 \\
\hline 2 & II & 46 & 35 \\
\hline 3 & III & 40 & 30 \\
\hline & Julmah & 110 & 85 \\
\hline
\end{tabular}

Pelaksanaan penelitian dilaksanakan pada awal dan akhir tahun ajaran 2008/2009, penelitian ini dilaksanakan di MTs Ali Maksum Yogyakarta, berada di jalan K.H. Ali Maksum, Gang Cuwiri, Pondok Pesantren Ali Maksum, Komplek Diponogoro, Krapyak, Yogyakarta, 55011.

Dalam penelitian ini variabel yang digunakan adalah sebagai berikut:

1. Variabel terikat, adalah hasil ujian akhir semester 2 pada tahun ajaran 2008/2009 dengan melakukan pendokumentasian data dari sekolah.

2. Variabel bebas, adalah hasil ujian masuk dan hasil ujian akhir semester 1 pada tahun pelajaran 2008/2009 dengan melakukan pendokumentasian data hasil belajar di sekolah.

Pengumpulan data merupakan alat untuk mempermudah pengkajian data terhadap yang diteliti, terdapat hal utama yang mempengaruhi kualitas data hasil penelitian yaitu: kualitas instrumen penelitian dan kualitas 
pengumpulan data dan merupakan suatu cara bagaimana dapat diperoleh data mengenai hal-hal yang terkait dengan variabel-variabel, pengumpulan data yang digunakan penelitian adalah dokumentasi.20 Pengumpualan data dengan cara mengumpulkan semua perangkat yang akan digunakan untuk menganalisis prediksi tes ujian masuk terhadap hasil belajar pada tahun pertama dianataranya soal tes ujian masuk, jawaban hasil ujian masuk, nilai hasil ujian masuk, nilai semester I dan nilai semester II pada tahun pertama.

Metode analisis yang digunakan adalah anlisis regresi ganda dan validasi prediktif, yaitu untuk menguji prediktibilitas tes ujian masuk yaitu analisis prediksi sekor tes seleksi masuk (sebagai variabel bebas) dengan nilai kasik belajar pada tahun pertama (sebagi variabel terkait). Kepentingan analisis dengan menggunakan regresi ganda dalam hal ini sebatas untuk mengetahui seberapa dukungan dari masing-masing prediktor terhadap hasil belajar. dengan menggunakan computer program SPSS versi 15.00 fersi windows. ${ }^{21}$ Rumus regresi ganda yang digunakan adalah: ${ }^{22}$

$$
\begin{aligned}
& \hat{\mathrm{Y}}=\mathbf{a}_{\mathbf{0}}+\mathbf{a}_{1} \mathrm{X}_{1}+\mathbf{a}_{2} \mathrm{X}_{2} \\
& \sum \mathrm{Y}=\mathrm{a}_{0} \mathrm{n}+\mathrm{a}_{1} \sum \mathrm{X}_{1}+\mathrm{a}_{2} \sum \mathrm{X}_{2} \\
& \sum \mathrm{YX}_{1}=\mathrm{a}_{0} \sum \mathrm{X}_{1}+\mathrm{a}_{1} \sum \mathrm{X}_{1}^{2}+\mathrm{a}_{2} \sum \mathrm{X}_{1} \mathrm{X}_{2} \\
& \sum \mathrm{YX}_{2}=\mathrm{a}_{0} \sum \mathrm{X}_{2}+\mathrm{a}_{1} \sum \mathrm{X}_{1} \mathrm{X}_{2}+\mathrm{a}_{2} \sum \mathrm{X}_{2}^{2} \\
& b_{1}=\frac{\sum_{i=1}^{n}\left(x_{i}-\bar{x}\right)\left(y_{i}-\bar{y}\right)}{\sum_{i=1}^{n}\left(x_{i}-\bar{x}\right)^{2}} \\
& b_{0}=\bar{Y}-b_{1} \bar{X}
\end{aligned}
$$

${ }^{20}$ Suharsimi Arikunto,Prosedur Penelitian suatu Pendekatan Praktik, (Jakarta: Rineka Cipta, 2006), hlm. 121

${ }^{21}$ Singgih Santoso, SPSS Versi10, (Jakarta: Gramedia, 2011)

${ }^{22}$ Ronald E. Walpole, Pengantar Statistika, (Jakarta: Gramedia Pustaka Utama, 1997), hlm. 223 
Validitas prediktif adalah memprediksi artinya meramal, dengan meramal selalu mengenai hal yang akan dating yang terjadi sekarang belum terjadi. Sebuah tes dikatakan memiliki validitas prediksi atau validitas ramalan apabila mempunyai kemmpun untuk meramalkan apa yang akan terjadi pada masa yang akan datang. ${ }^{23}$ Pengujian ini dilakukan dengan menghitung koefisien korelasi antara skor ujian masuk dengan hasil belajar tahun pertama. Semakin tinggi koefisien korelasi antara skor ujian masuk dan hasil belajar berarti validitas tes ujian masuk semakin baik. ${ }^{24}$ Rumus korelasi yang digunakan adalah rumus korelasi product moment dengan angka kasar;

$$
\mathbf{r}_{\mathrm{XY}}=\frac{\mathbf{N} \sum \mathbf{X Y}-\left(\sum \mathrm{X}\right)\left(\sum \mathrm{Y}\right)}{\sqrt{\left\{\mathrm{N} \sum \mathrm{X}^{2}-\left(\sum \mathrm{X}\right)^{2}\right\}\left\{\mathbf{N} \sum \mathrm{Y}^{2}-\left(\sum \mathrm{Y}\right)^{2}\right\}}}
$$

\section{HASIL DAN PEMBAHASAN}

Hasil penelitian dan pembahasan pada perangkat tes ujian masuk MTs Ali Maksum dapat diperoleh sebagai berikut:

Tes seleksi masuk atau ujian masuk MTs Ali Maksum yang dilaksanakan pada tahun pelajaran 2008/2009 pada bulan Juni 2008, dengan alat tes berupa soal sebanyak 10 soal logika matematik dan logika bahasa Indonesia. Dari hasil ujian masuk (UM) dan hasil belajar Ujian Akhir Semester 1 (UAS 1) dan Ujian Akhir Semester 2 (UAS 2) diperoleh hasil yang maksimal. Hasil analisis dengan menggunakan analisis regresi linear ganda menunjukan;

${ }^{23}$ Suharsimi Arikunto, Prosedur Penelitian suatu Pendekatan Praktik, ( Jakarta: Rineka Cipta, 2006), hlm. 69

${ }^{24}$ Saefudin Azwar, Reabilitas dan Validitas, (Yogyakarta, Pustaka Pelajar, 2007), hlm.140 
Tabel 3

Mean dan Standar Deviasi UM, UAS1 dan UAS2

\begin{tabular}{|l|r|r|r|}
\hline & \multicolumn{1}{|c|}{ Mean } & \multicolumn{1}{c|}{$\begin{array}{c}\text { Std. } \\
\text { Deviation }\end{array}$} & \multicolumn{1}{|c|}{ N } \\
\hline UAS2 & 131.9176 & 11.5853 & 85 \\
\hline UM & 47.6471 & 9.4096 & 85 \\
\hline UAS1 & 130.0000 & 12.6773 & 85 \\
\hline
\end{tabular}

Rata-rata UAS 2 dengan jumlah siswa 85 adalah 131,9176 dibulatkan 131, 92 dengan standar deviasi 11, 5853, UAS 1 130,00 dengan standar deviasi 9,4096, dan ujian masuk 130,00 dengan standar deviasi 12, 6773. Dengan tingkat korelasi yang berbeda sebagai berikut:

\section{Tabel 4}

\section{Korelasi dan Taraf Signifikansi}

\begin{tabular}{|l|l|r|r|r|}
\hline & & \multicolumn{1}{c|}{ UAS2 } & \multicolumn{1}{c|}{ UM } & \multicolumn{1}{c|}{ UAS1 } \\
\hline \multirow{4}{*}{ Pearson Correlation } & UAS2 & 1.000 & .312 & .756 \\
\cline { 2 - 5 } & UM & .312 & 1.000 & .274 \\
\cline { 2 - 5 } & UAS1 & .756 & .274 & 1.000 \\
\hline \multirow{3}{*}{ Sig. (1-tailed) } & UAS2 &. & .002 & .000 \\
\cline { 2 - 5 } & UM & .002 &. & .006 \\
\cline { 2 - 6 } & UAS1 & .000 & .006 &. \\
\hline $\mathbf{N}$ & UAS2 & 85 & 85 & 85 \\
\cline { 2 - 6 } & UM & 85 & 85 & 85 \\
\cline { 2 - 6 } & UAS1 & 85 & 85 & 85 \\
\hline
\end{tabular}

Besar hubungan antara variabel UAS 2 dengan ujian masuk (UM) yang dihitung dengan koefisien korelasi adalah 0,274 , sedangkan variabel ujian masuk dengan UAS 1 lebih besar yaitu 1,000, maka variabel ujian masuk lebih berpengaruh terhadap ujian UAS 2 dibanding dengan variabel UAS 1. Dengan demikian terjadi korelasi yang cukup kuat antara variabel ujian masuk dengan UAS 1 yaitu 0,274 hal ini menujukkan bahwa adanya korelasi di variabel terikat dan variabel bebas . 
Tingkat signifikansi koefisien korelasi menghasilkan angka 0,000 atau 0 . Oleh karena probabilitas jauh dibawah 0,05 , maka korelasi diantara variabel UAS 2 dengan Ujian masuk dan UAS 1 sangat nyata. Hasil analsis ujian masuk UAS 1 dan UAS 2 menunjukkan adanya perubahan yang signifikan terhadap hasil belajar siswa.

\section{Tabel 5}

Coefisien pada Persamaan Regresi

\begin{tabular}{|l|l|r|r|r|r|c|}
\hline & & \multicolumn{2}{|c|}{$\begin{array}{c}\text { Standard } \\
\text { ized } \\
\text { Model }\end{array}$} & $\begin{array}{c}\text { Unstandardized } \\
\text { Coefficients } \\
\text { nts }\end{array}$ & $\mathbf{t}$ & Sig. \\
\hline & & B & Std. Error & Beta & B & $\begin{array}{c}\text { Std. } \\
\text { Error }\end{array}$ \\
\hline 1 & (Constant) & 39.115 & 8.720 & & 4.485 & .000 \\
\hline & UM & .140 & .091 & .113 & 1.530 & .130 \\
\hline & UAS1 & .663 & .068 & .725 & 9.789 & .000 \\
\hline
\end{tabular}

a Dependent Variable: UAS2

Konstanta sebesar 39, 115 menyatakan jika tidak ada nilai ujian masuk atau UAS 1 maka prediksi nilai UAS 2 adalah 39,115, dengan koefisien regresi X1 sebesar 0,140 menyatakan bahwa setiap penambahan nilai 1 pada ujian masuk akan meningkatkan nilai UAS 2 sebesar 0,140, sedangkan koefisien regresi X2 sebesar 0,663, menyatakan bahwa setiap penambahan nilai satu pada nilai UAS 1 akan meningkatkan nilai UAS 2 sebesar 0,663. 


\section{Tabel 6}

Prediksi

\begin{tabular}{|l|r|r|r|r|r|}
\hline & Minimum & Maximum & \multicolumn{1}{c|}{ Mean } & \multicolumn{1}{c|}{$\begin{array}{c}\text { Std. } \\
\text { Deviation }\end{array}$} & N \\
\hline $\begin{array}{l}\text { Predicted } \\
\text { Value }\end{array}$ & 118.0489 & 157.9181 & 131.9176 & 8.8520 & 85 \\
\hline Residual & -17.7802 & 25.3575 & $\begin{array}{r}1.037 \mathrm{E}- \\
14\end{array}$ & 7.4741 & 85 \\
\hline $\begin{array}{l}\text { Std. } \\
\text { Predicted } \\
\text { Value }\end{array}$ & -1.567 & 2.937 & .000 & 1.000 & 85 \\
\hline Std. Residual & -2.350 & 3.352 & .000 & .988 & 85 \\
\hline
\end{tabular}

a Dependent Variable: UAS2

UJI KOEFISIEN REGRESI DARI VARIABEL UJIAN MASUK Hipotesis

$\mathrm{H} 0=$ koefisien regresi tidak signifikan

$\mathrm{H1}=$ koefisien regresi signifikan

Pengambilan keputusan

a. Dengan membandingkan statistik hitung dengan statistik tabel.

Jika satatistik thitung $<$ statistik t tabel, maka $\mathrm{H} 0$ diterima Jika satatistik thitung $>$ statistik t tabel, maka $\mathrm{H} 0$ ditolak

Dari tabel di atas terlihat t hitung sebesar 1,530, sedangkan statistik tabel dengan tingkat signifikansi $5 \%$, dengan derajat keabsahan $=$ jumlah data -2 atau $85-2=83$ dan dilakukan uji dua sisi

Keputusan: Oleh karena statistik hitung $>$ satatistik tabel maka $\mathrm{H} 0$ ditolak

b. Berdasarkan probabilitas

Jika probabilitas $>0,05$, maka $\mathrm{HO}$ di terima

Jika probabilitas $<0,05$, maka H0 di tolak

Kesimpulan:

Terlihat bahwa pada kolom signifikansi adalah 0,000 atau probabilitas dibawah 0,05, maka $\mathrm{H} 0$ ditolak, atau koefisien 
regresi signifikan, atau nilai ujian masuk MTs Ali Maksum benar-benar berpengaruh secara signifikan terhadap hasil belajar pada satu tahun pertama (UAS 1 dan UAS 2).

\section{Partial Regression Plot}

\section{Dependent Variable: UAS2}

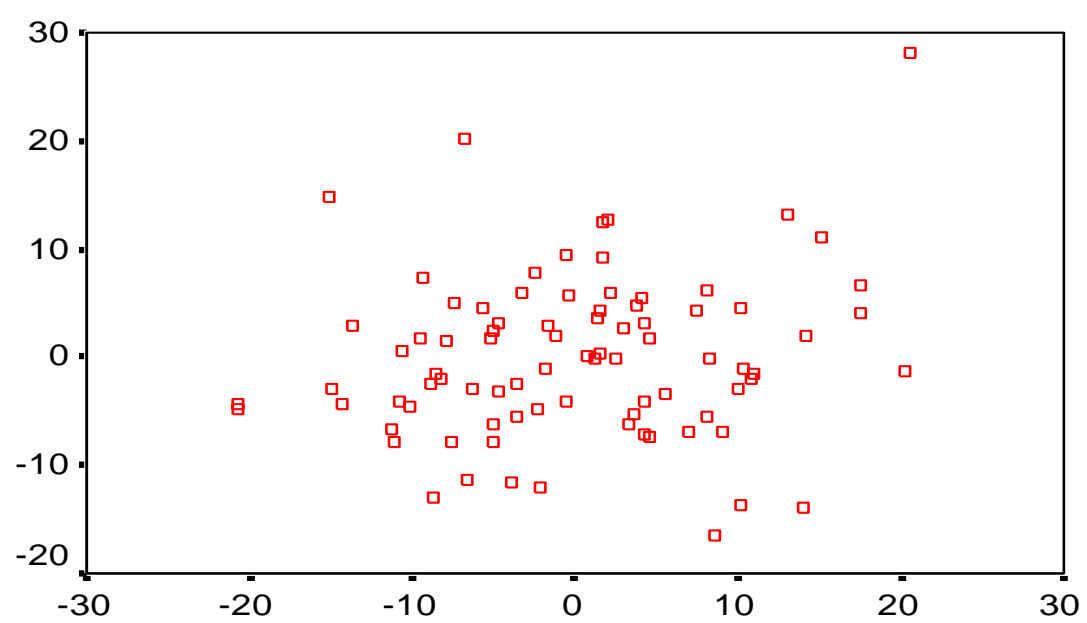

UM

Gambar 1

Prediksi Hasil Ujian Masuk dan UAS Genap 


\section{Partial Regression Plot}

\section{Dependent Variable: UAS2}

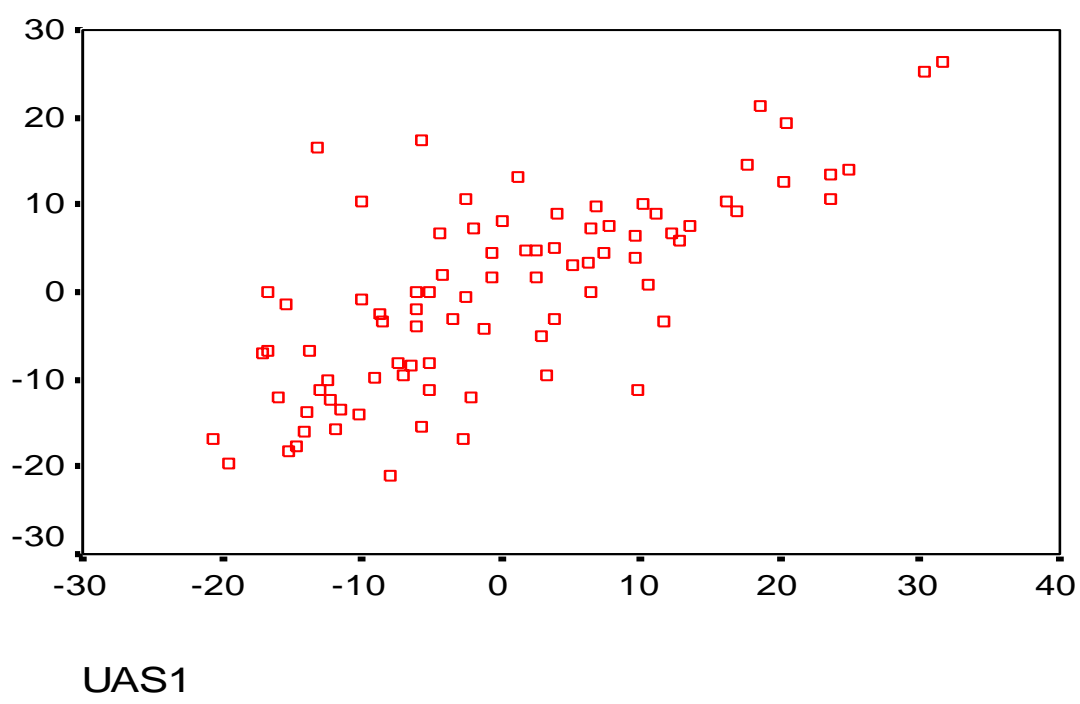

Gambar 2

Prediksi Hasil UAS Ganjil dan UAS Genap 


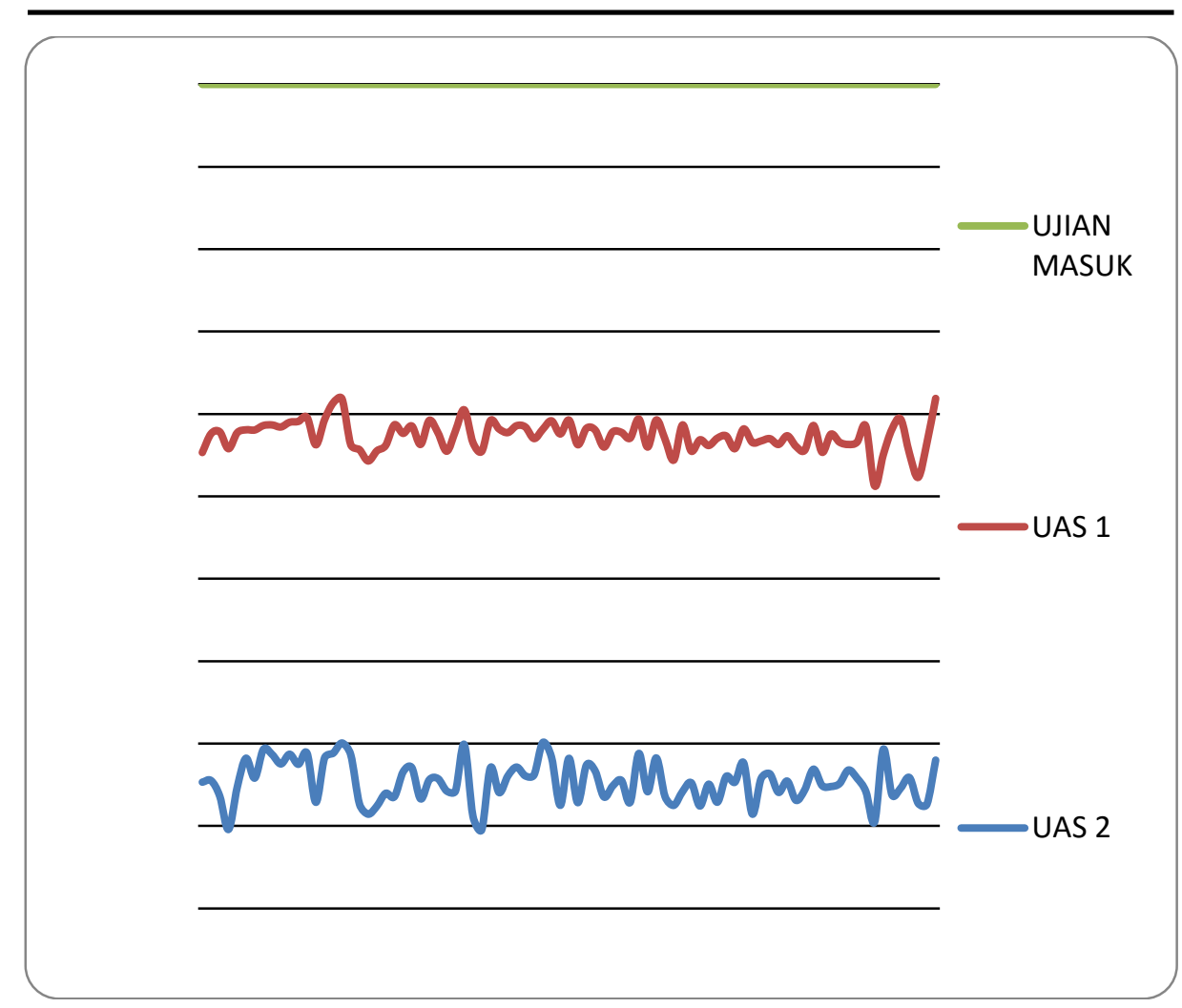

Gambar 3

Grafik hasil ujian masuk, UAS Gasal, dan UAS Genap 


\section{E. KESIMPULAN}

Berdasarkan hasil penelitian dan pembahasan di atas, dapat ditarik kesimpulan: Analisis Validitas Prediksibilitas Ujian Masuk Terhadap Hasil Belajar Satu Tahun Kedepan Di MTs Ali Maksum dengan analisis regresi menunjukka bahwa Ujian Masuk MTs Ali Maksum mempunyai daya prediktif yang tinggi dan berpengaruh terhadap hasil belajar siswa pada tahun pertama yang dapat dilihat dari hasil belajar pada ujian akhir semester 1 (UAS 1) dan Ujian akhir semester 2 (UAS 2) menunjukan bahwa ujian masuk mempunyai daya prediksi yang signifikan terhadap UAS 1 dn UAS 2. 


\section{DAFTAR PUSTAKA}

Anas Sudjiono,1998, Pengantar evaluasi pendidikan, PT. Raja Gravindo Persada, Jakarta

Conny Semiawan Stamboel, 1982, Prinsip dan Teknik Pengukuran dan Penilaian Di Dalam Dunia Pendidikan, Mutiara, Jakarta

Daryanto, 2005, Evaluasi Pendidikan, Rineka Cipta, Jakarta.

Djemari Mardapi, 2008, Teknik Penyusunan Instrumen Tes dan Non Tes, Mitra Cendikia, Yogyakarta.

Kabul Mulyana, 2006, Jurnal Penelitian dan Evaluasi Pendidikan Karakteristik Soal Tes Ujian Masuk SMP Negeri Kabupaten Bantu.

Nana Sudjana, 2002, Penilaian Hasil Proses Belajar Mengajar,Remaja Rosdakarya, Bandung

1986, Dasar-Dasar Proses Belajar Mengajar, Sinar baru Algasindo, Bandung

Nurjan, Syarifan, dan kawan-kawan, 2009, Psikologi Belajar, LAPISPGMI, Surabaya

Ronald E. Walpole, 1995, Pengantar Statistika, Gramedia Pustaka Utama, Jakarta

Saefudin Azwar, Reabilitas dan Validitas, Pustaka Pelajar Yogyakarta Singgih Santoso, 2001, SPSS Versi10, Gramedia, Jakarta

Sudjana, 20002, Metoda Statistika,Tarsito, Bandung

Suharsimi Arikunto,, 2006, Prosedur Penelitian suatu Pendekatan Praktik, Rineka Cipta, Jakarta.

2006, Dasar-dasar Evaluasi Pendidikan (Edisi Revisi), Bumi Aksara, Jakarta.

Sugiono, 2007, Metode Penelitian Pendidikan Pendekatan Kualitatif, Kuantitatif, dan R \& D, Alfabeta, Bandung.

Sugihartono,dkk,2007, Psikologi Pendidikan Cet. A , UNY Press, Yogyakarta

W.J.S. Poerwadarminta, Kamus Umum Bahasa Indonesia, cet. Ke-8, Balai Pustaka, Jakarta

Zaenal Arifin, 2012, Evaluasi Pembelajaran Prinsip Teknik Prosedur, PT. Remaja Rosda Karya, Bandung 